\title{
Pelatihan Pembuatan Laporan Rekapitulasi Keluarga Prasejahtera Pada Kecamatan Karawang Barat
}

\author{
Mohammad Syamsul Azis \\ STMIK Nusa Mandiri, mohammad.myz@nusamandiri.ac.id
}

\begin{abstract}
Abstrak
Komputer adalah perangkat yang tidak bisa lepas dari dunia kerja, apalagi penggunanya terus meningkat dari tahun ke tahun. Sehingga orang tidak bisa lepas dengan satu perangkat ini. Seperti halnya negara kita negara Indonesia yang sebagian besar penduduknya sudah menggunakan perangkat ini untuk meyelesaikan berbagai tugas. Dengan pentingnya manfaat komputer ini tentunya sistem pemerintahan pun wajib menggunkan perangkat ini agar tugas-tugas di negara ini semakain cepat terselesaikan dan lebih tepat sasaran, dibandingkan hanya mengandalakan kemampuan menulis atau teknik-teknik konvensional yang dirasa bisa memakan waktu yang lama dan kurang optimal. Oleh karena itu, kegiatan pengabdian kepada masyarakat ini dilakukan dengan tujuan untuk meningkatkan pengetahuan dan kemampuan masyarakat agar dapat menerapkan program kerja yang berbasis komputer. Kegiatan pertama terdiri dari satu hari membuat laporan dengan menggunakan microsoft excel, kemudian dilanjutkan dengan membuat surat menyurat menggunakan micorsoft word, dan ditutup dengan memberikan ketrampilan masyrakat dalam hal presentasi menggunakan power point. Setelah diadakannya pengabdian ini diharapkannya masyarakat yang terdapat pada lembaga pemerintahan mampu mengoperasikan tugas-tugasnya dengan komputer dengan baik dan menghasilkan hasil yang lebih optimal dibandingkan hasil yang sebelumnya yang masih menggunakan cara konvensional dan manfaatnya bisa dirasakan bagi petugasnya dan masyrakat yang dilayaninya serta bisa menjadi rujukan untuk kegiatan selanjutnya yang sejenis dengan pengabdian masyrakat ini.
\end{abstract}

Kata Kunci: pelatihan, laporan berbasis komputer, pengabdian kepada masyarakat

\begin{abstract}
The computer is a device that can not escape from the corporate world, let alone the users increased steadily from year to year. So that people do not go away with one this device. As well as our country state of Indonesia that most of its inhabitants already use these tools to complete various duties. With the importance of the benefits of this computer system of government will of course obliged to use this device that duties in this country to quickly resolved and reaching the target. Hence, devotion activities for the public was practiced with a view to advance their knowledge and community's ability to apply based computer work programs. he first activity consisting of one day make a report by using microsoft excel, these were then followed by make administration papers use micorsoft word, and covered with give skills the community in terms of use power point presentation. After arranging this devotion had hoped for the community are in government institutions able to operate its duties with a
\end{abstract}


Jurnal Pengabdian Kepada Masyarakat

computer with good and producing results that optimized compared the results of which were still using a conventional manner and benefits can be felt for his personnel and the community it serves as well as be a reference to the kind of devotion and. this community.

\section{Keywords: training, report of computer base, public service}

\section{Pendahuluan}

\section{Latar belakang pengabdian kepada masyarakat}

Berdasarkan survey Indonesia Baik pada tahun 2018, jumlah pengguna komputer jinjing yang disebut dengan laptop tanpa terhubung atau terkoneksi dengan internet di Indonesia sebanyak 54,55 persen digunakan untuk bekerja dan 53,65 persen digunakan untuk belajar serta 34,94 persen dari 2.122 responden. Sedangkan laptop yang terhubung dengan internet sebanyak dengan tujuan untuk mencari informasi dan bekerja sebesar 67,35 persen dan 67,08 persen sedangkan untuk keperluan belajar, dan komunikasi sebesar 40 persen. Persentase tersebut bisa dilihat lebih detail pada Tabel 1.

Tabel 1

Jumlah Pengguna Laptop di Indonesia

Saat Tidak Terhubung Internet

\begin{tabular}{|c|c|c|c|c|c|c|c|c|c|}
\hline \multicolumn{3}{|c|}{ Untuk Bekerja } & \multicolumn{3}{|c|}{ Untuk Belajar } & \multicolumn{4}{|c|}{ Untuk Hiburan } \\
\hline \multicolumn{2}{|c|}{$54,55 \%$} & & \multicolumn{3}{|c|}{$53,55 \%$} & \multicolumn{4}{|c|}{$34,94 \%$} \\
\hline \multicolumn{10}{|c|}{ Aktivitas Saat Tidak Terhubung Internet } \\
\hline $\begin{array}{c}\text { Menonton } \\
\text { Video dan } \\
\text { Mendengarkan } \\
\text { Musik } \\
\end{array}$ & $\begin{array}{c}\text { Bermain } \\
\text { Game }\end{array}$ & $\begin{array}{c}\text { Terhubung } \\
\text { Dengan } \\
\text { Perangkat } \\
\text { Baru } \\
\end{array}$ & $\begin{array}{l}\text { Transfer } \\
\text { File Antar } \\
\text { Perangkat }\end{array}$ & $\begin{array}{l}\text { Menginstall } \\
\text { Software }\end{array}$ & \multicolumn{2}{|c|}{$\begin{array}{l}\text { Menggunakan } \\
\text { Aplikasi } \\
\text { Offline }\end{array}$} & $\begin{array}{c}\text { Membaca } \\
\text { E-Book }\end{array}$ & $\begin{array}{l}\text { Desain } \\
\text { Grafis }\end{array}$ & $\begin{array}{l}\text { Membuat } \\
\text { Program } \\
\text { Komputer }\end{array}$ \\
\hline $38,66 \%$ & $29,47 \%$ & $24,42 \%$ & $13,58 \%$ & $13,58 \%$ & \multicolumn{2}{|c|}{$13,11 \%$} & $13,11 \%$ & $6,18 \%$ & $33,68 \%$ \\
\hline \multicolumn{10}{|c|}{ Saat Terhubung Internet } \\
\hline \multicolumn{2}{|c|}{$\begin{array}{l}\text { Untuk Mencari } \\
\text { Informasi }\end{array}$} & \multicolumn{2}{|c|}{ Untuk Bekerja } & \multicolumn{2}{|c|}{ Untuk Hiburan } & \multicolumn{3}{|c|}{ Untuk Belajar } & $\begin{array}{c}\text { Untuk } \\
\text { Komunika } \\
\text { si }\end{array}$ \\
\hline \multicolumn{2}{|l|}{$54,55 \%$} & $67,08 \%$ & & \multicolumn{2}{|l|}{$36,84 \%$} & \multicolumn{3}{|c|}{$34,16 \%$} & $33,67 \%$ \\
\hline \multicolumn{10}{|c|}{ Aktivitas Saat Terhubung Dengan Internet } \\
\hline \multicolumn{5}{|c|}{ Browsing } & \multicolumn{5}{|c|}{$74,69 \%$} \\
\hline \multicolumn{5}{|c|}{ Email/Chatting } & \multicolumn{5}{|c|}{$42,63 \%$} \\
\hline \multicolumn{5}{|c|}{ Unggah/Unduh File } & \multicolumn{5}{|c|}{$37,80 \%$} \\
\hline \multicolumn{5}{|c|}{ Streaming Video/Musik/Radio } & \multicolumn{5}{|c|}{$31,53 \%$} \\
\hline \multicolumn{5}{|c|}{ Menggunkan Aplikasi Online } & \multicolumn{5}{|c|}{$24,42 \%$} \\
\hline \multicolumn{4}{|c|}{ Bermain Game } & & \multicolumn{5}{|c|}{$24,13 \%$} \\
\hline \multicolumn{4}{|c|}{ Konfigurasi Software } & & & & 22,41 & & \\
\hline & Unduh/ & Membaca E-I & ook & & & & 19,79 & & \\
\hline & Bertr & nsaksi Onli & & & & & 9,71 & & \\
\hline & embuat & Program Ko1 & puter & & & & 5,58 & & \\
\hline
\end{tabular}

Sumber : https://indonesiabaik.id/infografis/jumlah-pengguna-laptop-di-indonesia-17

Dari Tabel 1 diketahui bahwa Indonesia sebagian besar penduduknya bergantung dengan perangkat komputer yang dalam kesehariannya banyak digunakan dalam 
berbagai aktivitas. Mulai dari untuk bekerja, untuk belajar, dan untuk hiburan. Selain itu ada aktivitas masyarakat yang terhubung dengan internet dengan tujuan untuk mencari informasi, untuk bekerja, mencari hiburan, untuk belajar dan untuk berkomunikasi. Fenomena ini menyebabkan banyaknya orang menggunakan perangkat komputer terutama laptop, dikarenakan laptop lebih mudah dibawa dan lebih praktis. Meskipun demikian untuk tempat-tempat perkantoran masih menggunakan komputer dekstop dikarenakan kondisi dan kebutuhan. Dengan adanya fenoma ini membuat dinas-dinas pemerintahan pun ikut menggunakan fasilitas komputer untuk mendukung kinerja pemerintahan agar kinerja untuk pelayanan terhadap masyrakat lebih optimal. Karena pemerintahan yang baik tentunya mampu mengikuti perkembangan zaman yang berjalan bukan statis tidak bergerak dan ketinggalan zaman. Sesuai dengan namanya, komputer (computer) berasal dari kata compute yang berarti menghitung. Proses dalam komputer merupakan operasi hitungan matematika. Komputer merupakan mesin berhitung elektronik yang dapat diprogram. Menurut Arifin (2009:7), komputer adalah "peralatan elektronika yang menerima masukan data, mengolah data dan memberikan hasil keluaran dalam bentuk informasi baik berupa teks, gambar, suara, maupun video." Sedangkan menurut Fauziah (2008:15) menyatakan bahwa, "komputer merupakan suatu sistem yang terdiri atas peralatan atau komponen perangkat keras (hardware) dan perangkat lunak (software) yang bekerja secara otomatis." Jadi menurutnya, komputer bukan hanya sekedar mesin hitung atau penyimpanan data dan komputer dapat memabantu manusia dalam mengerjakan tugas dan yang semakin banyak dan kompleks. Kesimpulan dari para pakar tersebut membuktikan bahwa komputer berperan penting dalam kehidupan masyrakat tidak hanya sebagai alat hitung melainkan juga berfungsi sebagai alat/mesin untuk menyelesaikan berbagai tugas.

Dampak dari penggunaan komputer baik secara online ataupun offline sudah terasa di masyrakat, diantaranya kecenderuangan masyrakat untuk mencari informasi yang tadinya mengandalkan koran dan sejenisnya sekarang dengan menggunakan komputer yang dihubungkan ke internet masyrakat lebih cepat dalam mencapatkan informasi bahkan sampai dengan penjualan pun masyrakat menggunakan komputer untuk mengelola data keuangannya ataupun memasarkan produknya. Sementara di level pemerintahan pun yang tadinya mengetik menggunakan mesin ketik beralih untuk mengerjakan menggunakan komputer yang disaat salah pun bisa tinggal hapus tanpa harus mengganti karbon. Sedangkan dampak bagi anak-anak pun ada, seperti halnya bermain game dengan menggunakan komputer tanpa harus membeli mainan untuk medianya.

Menanggapi kejadian tersebut di masyarakat, setiap elemen masyarakat secara langsung beradaptasi dengan perkembangan teknologi informasi yang ada agar dapat menyesuaikan dengan perubahan aktivitas sehari-hari baik dalam bekerja ataupun dalam aktivitas lainnya. Apabila setiap instansi atau lembaga tidak mampu beradaptasi dengan kemajuan teknologi saat ini, maka secara langsung akan mengalami ketertinggalan dalam berbagai sektor. Dan pastinya lambat laun akan berpengaruh dengan keberlangsungan sistem yang berjalan pada instansi atau lembaga tersebut. 
Menanggapi fenomena tersebut Program Studi Sistem Informasi Sekolah Tinggi Manajemen Informatika dan Komputer Nusa Mandiri Jakarta (STMIK Nusa Mandiri Jakarta), menyelenggarakan kegiatan pengabdian masyarakat bagi Instansti yang terdapat di daerah yang terjangkau oleh kampus. Sebagai objek pengabdian yang terpilih adalah Kecamatan Karawang Barat. Adapun Kecamatan sebaga objek pengabdian disini dikarenakan instansi tersebut sebagian besar SDM nya masih gagap dengan teknologi, faktor lain karena usia yang sudah lanjut dan peralatan yang masih konvensional. Metode administrasi saat ini adalah dengan menggunakan mesin ketik untuk surat menyurat dan membuat laporan. Berdasarkan wawancara dengan camat, SDM pada kecamatan karawang barat masih gagap teknologi dan kurang mampu merespon cepat perkembangan saat ini, sehingga kebutuhan masyrakat yang banyak membutuhkan pelayanan yang maksimal dan optimal. Hal ini disebabkan karena belum adanya pelatihan komputer dan fasilitas lama yang masih sampai sekarang digunakan. Meskipun sebagian komputer sudah ada, tapi tidak semua SDM mampu mengoperasikannya. Hal ini disebabkan SDM masih terbiasa denga mesin-mesin lama.

\section{Tujuan dan manfaat pengabdian kepada masyarakat}

Kegiatan pengabdian masyarakat ini bertujuan untuk Pertama, meningkat kualitas SDM dalam bidang komputer, meningkatkan kualitas pelayanan kepada masyarakat; Kedua, sebagai salah satu wujud pelaksanaan tri dharma perguruan tinggi yaitu mentransformasikan, mengembangkan, dan menyebarluaskan ilmu pengetahuan, teknologi, dan informasi kepada masyarakat.

Adapun manfaat kegiatan pengabdian masyarakat ini adalah pertama, bagi intstansi terkait, yaitu meningkatkan pengetahuan dan keterampilan sumber daya manusia dalam adminitrasi dan pelayanan masyrakat berbasis komputer; Kedua, meningkatkan kepuasaan masyrakat dalam hal pelayanan berbasis komputer; Ketiga, bagi dosen dan mahasiswa, yaitu mendapatkan data dan informasi terkini mengenai penerapan ilmu pengetahuan, teknologi dan informasi di kalangan masyarakat dalam rangka pengkajian ilmiah dan pengembangan ilmu pengetahuan, teknologi dan informasi.

\section{Kajian pustaka}

Terkait kegitan tersebut berikut kajian pustaka yang memuat teori dan konsep yang menjadi dasar pelaksanaan pelatihan, pendampingan pembuatan laporan dengan berbasis komputer di Kecamatan Karawang Barat.

a. Pelatihan dan pendampingan

Menurut Mondy(dalam Lukmanul Hakim (2019:77)), pelatihan adalah aktivitasaktivitas yang dirancang untuk memberi para pembelajar pengetahuan dan keterampilan yang dibutuhkan sesuai pekerjaan mereka saat ini. Sedangkan menurut Dessler (dalam Lukmanul Hakim (2019:77)), mendefinisikan pelatihan sebagai proses mengajar keterampilan yang dibutuhkan karyawan baru untuk melakukan pekerjaannya. Pelatihan juga bisa diartikan sebagai kegiatan penyampaian informasi dari pembicara kepada peserta dengan tujuan untuk meningkatkan pengetahuan yang dibutuhkan oleh peserta dalam melaksanakan 
pekerjaannya (Hakim ,2019:78). Tentunya dalam pelatiahan pastinya ada beberapa tahap. Diantaranya tahapan pertama harus mengetahui kebutuhannya, menentukan tujuan, bagaimana teknik penyampaiannya,baru melaksanakan pelatihannya dan melakukan evaluasi pada pelatihan yang dilakukan dan pada tahapan terkahirnya memberikan rekomendasi atas dasar evaluasi yang telah dilakukan.

\section{b. Laporan}

Menurut Keraf (2001: 284) laporan adalah suatu cara komunikasi dimana penulis menyampaikan informasi kepada seseorang atau suatu badan karena tanggung jawab yang dibebankan kepadanya. Berbeda dengan Mulyadi (2008:5) menurutnya laporan adalah keluaran sistem informasi akuntansi dan berbentuk hasil cetak komputer dan tayangan pada layar monitor komputer. Sedangkan menurut pendapat pakar lain, Rama dan Frederick L. Jones (2008:250) laporan adalah presentasi data yang telah terformat dan terorganisasi dengan baik. Dari sekian definisi laporan dapat disimpulkan bahwa laporan merupakan keluaran (output) dari suatu sistem baik yang sudah terkomputerisasi ataupun belum yang dibebankan pada suatu badan/bagian pada suatu instansi/organisasi tertentu yang terformat dan terorganisasi dengan baik dengan tujuan informasi yang disampaikan dapat diterima dengan baik (informatif).

Laporan yang baik dan informatif tentunya harus melalui tahapan yang baik dan benar agar hasil yang disampaikan akurat dan tepat. Karena jika laporan tidak jelas dan informasi menggantung tentunya akan membuat pembaca laporan kebingungan dan tidak mendapatkan informasi yang diinginkan. Tahapan pertama adalah mengetahui objek yang akan dibuat laporan, dan yang kedua mengumpulkan bahan-bahan laporannya, setelah itu menentukan metode pengumpulan datanya, kemudian di evaluasi data-datanya dan tahapan terakhir membuat kerangka laporannya lalu mengevaluasinya kembali agar tidak ada kesalahan data dan jelas akuratnya data yang dijadikan laporan.

\section{c. Rekapitulasi}

Informasi Rekapitulasi menurut Amsyah (2005:296) merupakan informasi ringkas dengan hasil akhir dari suatu perhitungan (kalkulasi) atau gabungan perhitungan yang berisikan angka-angka yang disajikan dalam bentuk kolom-kolom. Dari definisi tersebut dapat ditarik kesimpulan bahwa rekapitulasi adalah ringkasan dari hasil akhir dari suatu perhitungan (kalkulasi) atau gabungan perhitungan yang berisikan angka-angka yang disajikan dalam bentuk kolom-kolom.

\section{d. Keluarga Prasejahtera}

Menurut Suprajitno (2004:1), keluarga merupakan bagian dari manusia yang setiap hari selalu berhubungan dengan kita. Keadaan ini kita perlu sadari sepenuhnya bahwa setiap individu merupakan bagiannya dan di keluarga juga semua dapat diekspresikan tanpa hambatan yang berarti. Pengertian keluarga akan berbeda. Hal ini bergantung pada orientasi yang digunakan dan orang yang mendifinisikannya. Friedman (dalam Suprajitno 2004:1) mendifinisikan bahwa keluarga adalah kumpulan dua orang atau lebih yang hidup bersama dengan keterikatan aturan dan 
emosional dan individu mempunyai peran masing-masing yang merupakan bagian dari keluarga. Pakar konseling keluarga dari Yogyakarta, Sayekti (dalam Suprajitno 2004:1) menulis bahwa keluarga adalah suatu ikatan/persekutuan hidup atas dasar perkawainan antara orang dewasa yang berlainan jenis yang hidup bersama atau seorang laki-laki atau seorang perempuan yang sudah sendirian dengan atau tanpa anak, baik anaknya sendiri atau adopsi, dan tinggal dalam sebuah rumah tangga.

Berdasarkan kemampuan keluarga untuk pemenuhan kebutuhan dasar, kebutuhan psikososial, kemampuan memenuhi ekonominya, dan aktualisasi keluarga di masyrakat, serta memperhatikan perkembangan negara Indonesia menuju negara industri, Indonesia menginginkan terwujudnya Keluarga Sejahtera. Tetapi pada kenyataannya, tidak dapat dipungkiri jika dikalangan masyrakat terdapat keluarga yang disebut keluarga prasejahtera. Menurut Suprajitno(2004:7), keluarga prasejahter adalah keluarga yang dapat memenuhi kebutuhan dasar secara minimal, yaitu kebutuhan pengajaran agama, pangan, sandang, papan, dan kesehatan, atau keluarga yang belum dapat memenuhi salah satu atau lebih indikator keluarga sejahtera tahap I.

\section{Pertanyaan penelitian}

Berdasarkan uraian pendahuluan dan kajian pustaka, rumusan pertanyaan penulisan karya ilmiah ini adalah "Bagaimana pelaksanaan kegiatan pengabdian masyarakat di Kecamatan Karawang Barat melalui pelatihan pembuatan laporan rekapitulasi keluarga prasejahtera?"

\section{Metode}

1. Tahapan kajian yang digunakan untuk menyelesaikan permasalahan pengabdian

Tahapan pelaksanaan pengabdian masyarakat : (1) Pembentukan Tim Pengabdian kepada Masyarakat, yang disebut Tim Abdimas; (2) Penyusunan proposal kegiatan; (3) Kajian pustaka; (4) Penyusunan materi dan modul pelatihan; (5) Kunjungan Tim Abdimas ke Kecamatan Karawang Barat; (6) Pelatihan Pembuatan Laporan Rekapitulasi Keluarga Prasejahtera; (7) Pendampingan pembuatan laporan; (8) Penyusunan laporan kegiatan; (9) Publikasi kegiatan pengabdian kepada masyarakat dalam press realese dan jurnal ilmiah.

\section{Sumber Data, Teknik Pengumpulan Data dan Analisis data}

Penulisan karya ilmiah tentang pengabdian masyrakat ini dilakukan dengan metode pendekatan kualitatif. Menurut Denzin dan Lincoln (dalam Albi Anggito dan Johan Setiawan, 2018:7), penelitian kualitatif adalah penelitian yang menggunakan latar alamiah dengan maksud menafsirkan fenomena yang terjadi dan dilakukan dengan jalan melibatkan berbagai metode yang ada. Sedangkan menurut Ericson (dalam Albi Anggito dan Johan Setiawan, 2018:7) menyatakan bahwa penelitian kualitatif berusaha untuk menemukan dan menggambarkan secara naratif kegiatan yang dilakukan dan dampak dari tindakan yang dilakukan terhadap kehidupan mereka. Pada penelitian tentang pengabdian masyrakat ini menggunakan metode pengumpulan data seperti observasi, wawancara, dan dokumentasi. Observasi atau 
yang disebut dengan pengamatan ini dilakukan secara langsung oleh peneliti dengan cara mengamati proses-proses yang sedang berjalan dari awal hingga akhir kegiatan. Tahap berikutnya interview atau wawancara dilakukan dengan tutor, tim tutor dan peserta pelatihan. Sedangkan dokumentasi, bersumber dari proposal kegiatan, dokumentasi foto kegiatan, laporan kegiatan, dan press realese.

Penganalisisan data menggunakan metode deskriptif kualitatif. Metode ini pada hakikatnya merupakan jawaban kritis terhadap berbagai masalah yang dihadapi oleh metode kualitatif itu sendiri, sehubungan dnegan objek material penelitian berupa manusia dengan segala hasil budayanya (Wibowo, 2011:43).

\section{Hasil dan Pembahasan}

\section{Hasil}

Dalam kegiatan pengabdian kepada masyarakat ini memiliki empat tahapan, diantaranya tahapan pra-kegiatan, tahapan pelatihan, tahapan pendampingan, dan tahapan pascakegiatan. Keempat tahapan tersebut diuraikaan ke dalam bentuk Tabel 2. Tahap pertama, prakegiatan, terdiri dari : 1) Pembentukan panitia kegiatan yang disebut Tim Abdimas. Tim Abdimas terdiri dari 3 orang dosen program studi Sistem Informasi, Sekolah Tinggi Manajemen Informatika dan Komputer Nusa Mandiri Jakarta. Tiga orang dosen tersebut berperan sebagai konseptor, fasilitator, dan tutor; tahapan selanjutnya 2) Tim Abdimas menyusun proposal kegiatan yang diajukan kepada Ketua Sekolah Tinggi dan lembaga pemerintah; 3) Kajian pustaka terkait dengan pelatihan, pembuatan laporan, dan presentasi laporan. Kajian ini dilakukan untuk mencari konsep teori dan data-data empiris untuk menyusun modul pelatihan, materi presentasi pelatihan, dan panduan pendampingan; 4) Pengumpulan bahan materi ; 5) Survey lokasi dan observasi ke lembaga pemerintah, untuk mensosialisasikan kegiatan pelatihan dan pendampingan; sekaligus melakukan 6) perizinan kegiatan kepada lembaga pemerintah dan pendaftaran peserta pelatihan; Setelah mendapatkan data lembaga pemerintahan, lokasi, waktu, dan peserta kegiatan; proses selanjutnya 7) Tim Abdimas menyusun modul pelatihan; dan 8) melakukan pengadaan peralatan dan perlengkapan kegiatan. Tahapan kegiatan ini dilakukan hampir satu bulan pada bulan Oktober sampai dengan November 2018.

Tabel 2

Rincian Kegiatan Pengabdian Masyarakat

\begin{tabular}{|c|c|c|c|c|c|c|c|c|c|c|c|c|}
\hline \multirow{2}{*}{ No. } & \multirow{2}{*}{ Kegiatan } & \multirow{2}{*}{ Tahap } & \multirow{2}{*}{ Waktu } & \multicolumn{5}{|c|}{ Okt-2018 } & \multicolumn{4}{|c|}{ Nov-2018 } \\
\hline & & & & 1 & 2 & 3 & 4 & 5 & 1 & 2 & 3 & 4 \\
\hline 1 & Pembentukan Tim Abdimas & \multirow{8}{*}{ Prakegiatan } & 1 hari & & & & & & & & & \\
\hline 2 & Penyusunan proposal kegiatan & & 3 hari & & & & & & & & & \\
\hline 3 & Kajian pustaka & & 2 hari & & & & & & & & & \\
\hline 4 & Pengumpulan bahan materi & & 1 hari & & & & & & & & & \\
\hline 5 & Survey lokasi perusahaan mitra & & 1 hari & & & & & & & & & \\
\hline 6 & Sosialisasi pada perusahaan mitra & & 1 hari & & & & & & & & & \\
\hline 7 & Ijin kegiatan pada perusahaan mitra & & 1 hari & & & & & & & & & \\
\hline 8 & Pendaftaran calon peserta pelatihan & & 1 hari & & & & & & & & & \\
\hline
\end{tabular}


Jurnal Pengabdian Kepada Masyarakat

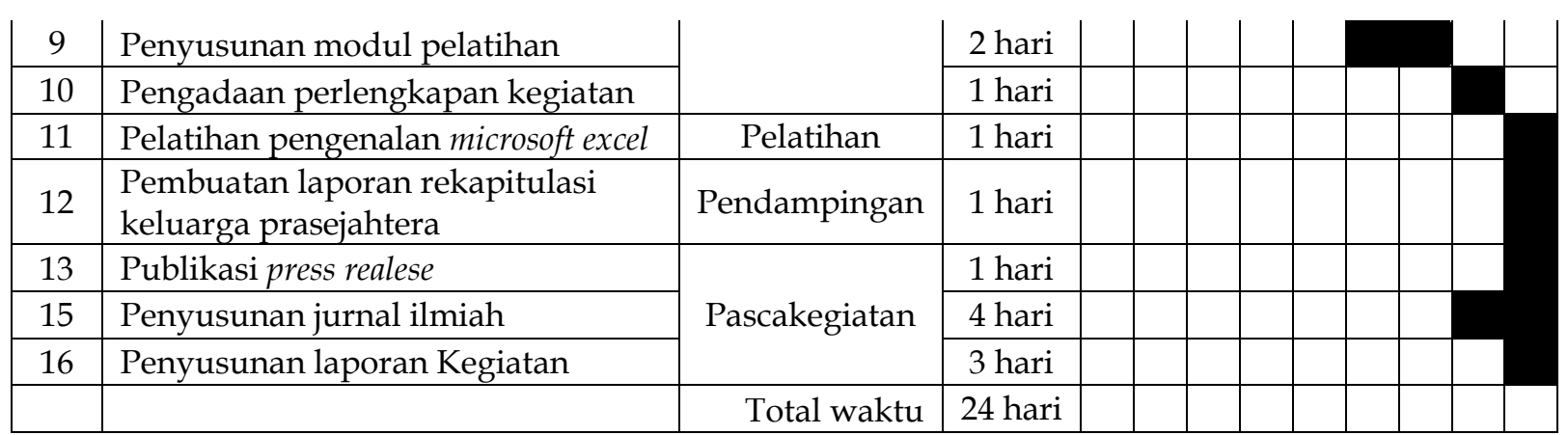

Sumber : Laporan Kegiatan Pengabdian Masyarakat Program Studi SI STMIK Nusa Mandiri Jakarta.

Tahap kedua, pelatihan. Pelatihan diselenggarakan di kampus UBSI pada hari 24 November 2018. Pelatihan dimulai pada pukul 09.00 dan berakhir pada pukul 13.00. Materi yang disampaikan oleh tutor tentang pengenalan microsoft excel dan arahan dalam pembuatan format laporan yang benar. Tutor pada penyampaian materi sebanyak satu orang dosen yang dibantu oleh asisten tutor sebanyak dua orang dosen dan dua orang mahasiswa. Peserta sebanyak empat belas orang yang terdiri dari staff kecamatan karawang barat. Saat penyampaian materi berlangsung di selasela waktunya peserta diperbolehkan untuk bertanya dan berdiskusi dengan tutor ataupu asisten tutor. Berikut dokumentasi pelatihan seperti pada Gambar 2 dan Gambar 3.

Tahap ketiga adalah pendampingan. Pendampingan dibagi menjadi pendampingan pembutan laporan selama satu hari yaitu pada hari Minggu, 25 November 2018, sejak pukul 09.00 sampai dengan pukul 13.00 WIB. Berbeda dengan sesi pada hari sebelumnya, untuk sesi pendampingan ini peserta dilatih untuk membuat laporan rekapitulasi keluarga prasejahtera dengan menggunakan microsoft excel. Disaat kendala terjadi pada pembuatan laporan, setiap asisten tutor siap membantu dalam mengatasi kendala tersebut. Peserta dibimbing langsung oleh tutor untuk membuat laporan rekapitulasi keluarga pra sejahtera berdasarkan materi yang telah disusun seperti pada Modul Pelatihan. Perlengkapan dalam pelatihan diantaranya laptop tutor, PC untuk peserta, projector, dan contoh format laporan dari kecamatan yang sudah ada sebelumnya.

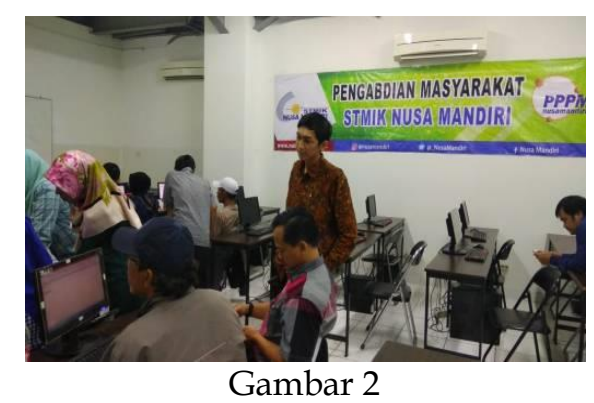

Pelatihan Pembuatan Laporan Keluarga

Prasejahtera

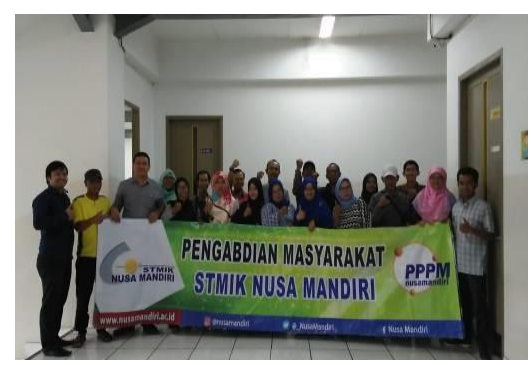

Gambar 3

Tutor dan Peserta Pelatihan

Membuat laporan ini memerlukan waktu sehari saja. Namun untuk mengasah ketrampilan dan kemampuan dalam mengoperasikan komputer perlu dilakukan secara rutin agar nantinya para staff kecamatan menjadi terbiasa membuat laporan 
dengan menggunakan komputer dan semakin terampil juga dalam menggunakan microsoft office tentunya microsoft excel. Para peserta perlu mengembangkan kemampuan mereka agar kedepannya laporan bisa dibuat menjadi lebih baik dari format yang sebelumnya, sehingga masyrakat menjadi semakin puas dengan pelayaanan dari staff kecamatan setempat. Oleh karena itu, pendampingan dilakukan oleh Tim Tutor selama kurang lebih satu bulan untuk monitoring proses pembuatan laporan rekapitulasi keluarga prasejahtera yang mereka buat. Setelah satu bulan pengawasn, diharapkan kecamatan karawang barat semakin bisa mengembangkan sistem-sistem konvensional beralih ke sistem komputer sehingga pelayanan masyrakat menjadi lebih maksimal dan kinerja kecamatannya sendiri pun semakin optimal.

Tahap akhir adalah pascakegitan yang meliputi 1) Publikasi kegiatan berupa press realese yang dimuat pada tanggal 27 November 2019 di media berita online nasional dan lokal. Kegiatan pengabdian kepada masyarakat ini, dilakukan dengan 2) Kegiatan diakhiri dengan penyusunan laporan kegiatan yang disampaikan kepada ketua sekolah tinggi sebagai bentuk pelaporan dan pemenuhan salah satu unsur beban kinerja dosen.

Seluruh rangkaian kegiatan pengabdian kepada masyarakat, menghasilkan empat luaran kegiatan Pertama, Peningkatan pemahaman dan keterampilan masyarakat mengenai ilmu komputer; Kedua, Implementasi laporan berbasi komputer berupa pembuatan laporan menggunakn komputer dengan aplikasi microsoft excel; Ketiga, modul pelatihan sebagai manual book yang berjudul "Pelatihan Pembuatan Laporan Keluarga Prasejahtera Menggunakan Microsoft Excel"; Keempat, publikasi kegiatan pada press realese pada media online.

\section{Pembahasan}

Pelatihan yang diselenggarakan memberikan pengetahuan kepada peserta tentang pembuatan laporan dengan basis komputer menggunakan microsoft excel. Setelah pelatihan, tahap selanjutnya pendampingan pembuatan laporan. Kegiatan ini sejalan dengan pendapatnya Mondy (dalam Lukmanul Hakim, 2019: 89) yang menyatakan bahwa pelatihan dirancang untuk memberikan pengetahuan dan keterampilan kepada peserta. Peserta pelatihan menggunakan pengetahuan dan keterampilan yang baru didapatkannya untuk pekerjaan mereka sehari-hari yaitu mengembangkan akun marketplace sebagai salah satu media pemasaran produkproduk perusahaan. Hal ini seperti yang disampaikan oleh Dessler (dalam Lukmanul Hakim, 2019: 89), bahwa pelatihan memang ditujukan agar peserta dapat melakukan pekerjaannya.

Proses pelatihan dan pendampingan yang diselengarakan oleh Tim Abdimas adalah untuk memeberikan keterampilan dalam menggunakan komputer memalui aplikasi office dalam membuat laporan. Selain itu untuk memenuhi kebutuhan dari kecamatan,yakni untuk meningkatkan optimalitas ketrampilan staff dalam membuat laporan. Dengan memanfaatkan kemampuan ini diharpakan pelayanan terhadap masyrakat makin maksimal dan kinerja pada staff di kecamatannya pun makin optimal. 
2) Menentukan tujuan yang spesifik. Tujuan dari pelatihan dan pendampingan adalah memberikan pengetahuan dan keterampilan teknis yaitu membuat laporan rekapitulasi keluarga prasejahtera; 3) Memilih metode dan sistem penyampaian dan pelatihan 4) Melaksanakan program, dengan kegiatan utama pelatihan dan pendampingan. Satu hari pengenalan materi berupa penyampaian materi kemudian pelaksanaan kegiatan pendampingan, yaitu pendampingan langsung berbasis komputer selama satu hari. Pada pendampingan ini tutor memberikan modul pelatihan kepada peserta dalam membuat laporan rekapitulasi keluarga prasejahtera. Model pelaksanaan pelatihan seperti ini diterima dengan baik oleh pihak kecamatan karena dirasa lebih efektif dan efisien;

Terakhir, 5) Mengevaluasi kegiatan. Evaluasi dilakukan setelah kegiatan ini berakhir untuk mengetahui seberapa besar manfaat ini berpengaruh pada kompetensi. Evaluasi dijadikan alat untuk mengukur dampak dari pemanfaatan komputer dalam pembuatan laporan rekapitulasi keluarga prasejahtera. Evaluasi bertujuan untuk memberikan rekomendasi sekaligus sebagai penilaian atas kegiatan yang telah diselenggarakan.

\section{Simpulan dan Rekomendasi}

Dapat disimpulkan bahwa kegiatan pengabdian kepada masyarakat berhasil diselenggarakan dengan metode satu hari pengenalan materi dan dilanjutkan dengan pendampingan berupa pemberian pelatihan pembuatan laporan. Proses kegiatan terdiri dari prakegiatan, pengenalan materi atau pembekalan materi, pendampingan pembuatan laporan, dan pascakegiatan. Evaluasi secara kuantitatif dilakukan untuk mengukur efektivitas kegiatan.

Rekomendasi usulan dari kegiatan pengabdian kepada masyarakat ini adalah menerapkan sistem terkomputerisasi pada pembuatan laporan dan kepada sistem yang berbhubungan dengan masalah administratif pada kecamatan karawang barat agar kinerja staff di kecamatan semakin maksimal dan pelayanan terhadap kebutuhan masyarakat pun mejadi lebih optimal. Karena dampak dari penerapan ini kinerja menjadi lebih efektif dan tujuan instansti bisa tercapai dengan efisiean.

\section{Daftar Pustaka}

Amsyah, Zulkifli. (2005). Manajemen Sistem Informasi. Gramedia Pustaka Utama, Jakarta.

Anggito, Albi dan Johan Setiawan. (2018). Metodologi Penelitian Kualitatif. Jejak, Sukabumi.

Arifin, Husnul, (2009). Panduan Membeli Komputer: Murah dan Berkualitas . Mediakom, Yogyakarta.

Fauziah, (2008). Jago Teknologi Informasi dan Komunikasi SMP. Media Pusindo, Depok.

Dasaratha V. Rama, dan Frederick L. Jones, (2008). Sistem Informasi Akuntansi. Salemba Empat, Jakarta. 
Hakim, Lukmanul, (2019). Pelatihan Pemasaran Online Berbasis Marketplace Bagi UMKM Dalam Merespon Perubahan Perilaku Konsumen. Jurnal Pengabdian Kepada Masyrakat. Volume II No.1. ISSN: 2621-4687.

Keraf, Gorys, (2001). Argumentasi dan Narasi. PT Gramedia Pustaka Utama, Jakarta. Mulyadi, (2008). Sistem Akuntansi. Salemba Empat, Jakarta.

Suprajitno, (2004). Asuhan Keperawatan Keluarga: Aplikasi Dalam Praktik. Kedokteran EGC, Jakarta.

Wibowo, Wahyu, (2011). Cara Cerdas Menulis Artikel Ilmiah. Kompas Media Nusantara, Jakarta. 